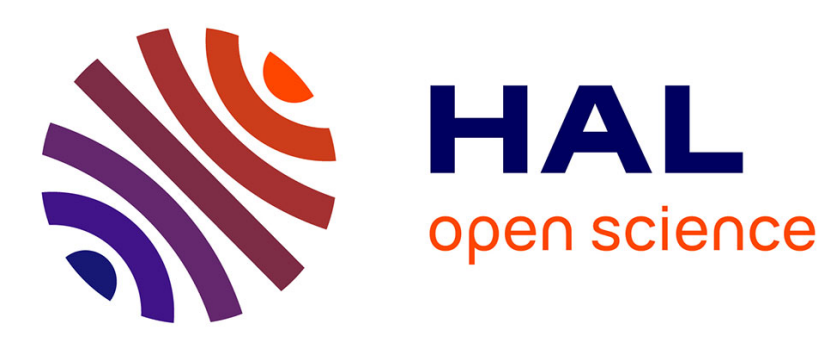

\title{
Exploring the concept of sustainable development through a simulation game
}

\author{
Odile Blanchard, Arnaud Buchs
}

\section{To cite this version:}

Odile Blanchard, Arnaud Buchs. Exploring the concept of sustainable development through a simulation game. 2010, 22 p. halshs-00498817

\section{HAL Id: halshs-00498817 https://shs.hal.science/halshs-00498817}

Submitted on 8 Jul 2010

HAL is a multi-disciplinary open access archive for the deposit and dissemination of scientific research documents, whether they are published or not. The documents may come from teaching and research institutions in France or abroad, or from public or private research centers.
L'archive ouverte pluridisciplinaire HAL, est destinée au dépôt et à la diffusion de documents scientifiques de niveau recherche, publiés ou non, émanant des établissements d'enseignement et de recherche français ou étrangers, des laboratoires publics ou privés. 


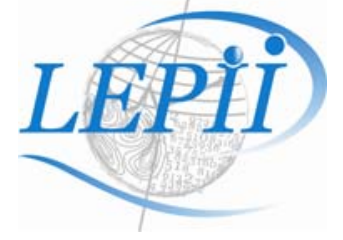

LABORATOIRE D'ECONOMIE DE LA PRODUCTION

ET DE L'INTEGRATION INTERNATIONALE

UMR 5252 CNRS - UPMF

\section{CAHIER DE RECHERCHE \\ $\mathbf{N}^{\circ} 35$}

\section{Exploring the concept of sustainable development through a simulation game}

\section{Odile Blanchard Arnaud Buchs}

juin 2010 



\title{
Exploring the concept of sustainable development through a simulation game
}

\author{
Odile BLANCHARD* and Arnaud BUCHS ${ }^{\circ}$
}

* Corresponding author,

Associate professor,

Université Pierre Mendès-France,

BP 47

38040 Grenoble,

France

Phone: + 33456528584

Fax: + 33456528571

Odile.Blanchard@upmf-grenoble.fr

$\circ \mathrm{PhD}$ student,

Université Pierre Mendès-France

BP 47

38040 Grenoble,

France

Phone: + 33456825410

Fax: + 33456528571

Arnaud.Buchs@upmf-grenoble.fr 


\section{Exploring the concept of sustainable development through a simulation game}

Abstract: The concept of sustainable development is used in everyday life by the general public, alongside researchers, institutions, and private companies. Nevertheless, its definition is far from being unequivocal. Clarifying the outline of the concept seems necessary. We have created a simulation game to address this goal. Our paper aims at bringing an overview of how the concept of sustainable development has emerged and spread over time, depicting the features of the game, and explaining how fruitful it is to the audience. The game is highly praised by the players as it not only brings them foundational knowledge, but also allows them to enhance many skills. The framework of the game thus contributes to educating about sustainable development as well as educating for sustainable development.

Key words: simulation game, sustainable development, education, significant learning JEL codes: A2, Q01

The concept of sustainable development emerged three decades ago and gained huge momentum after the release of the Brundtland report in 1987 (WCED 1987). It is now used in everyday life by the general public, alongside researchers, institutions and private companies. Nevertheless, its definition is far from being unequivocal. As J. Pezzey and M.A. Toman (2002, 2) put it: “overlapping and conflicting definitions rapidly proliferated. One result was that words such as 'sustainability' and 'sustainable' became common buzzwords motherhood-and apple-pie concepts mouthed approvingly by anyone from media moguls to multinational mining companies — that often meant nothing more than 'environmentally 
desirable' ". Clarifying the outline of the concept to students, but also to anyone referring to sustainable development, seems therefore necessary. We have created a simulation game to address this goal.

Our paper aims at bringing a short overview of how the concept of sustainable development has emerged and spread over time, as well as depicting the features of the game and explaining how fruitful it is to the audience, whoever the learners are. It is organised in two sections. The first one addresses the generating process and the definitions of the concept of sustainable development. We show that the three intertwined dimensions associated with sustainable development, i.e. economic growth, environmental constraints and social dynamics, had long been under scrutiny before the creation of the concept of sustainable development. However, the 1970s appear to be crucial.

The second section focuses on the game, its rules, and its learning potential. Learners are invited to role play an actor officially fully involved in sustainable development, and critically examine whether the approaches adopted by the various actors (players) can reasonably be qualified as sustainable. The framework of the game contributes not only to educating about sustainable development but also to educating for sustainable development (UN ECOSOC 1999). To assess the learning potential of the game, we use the taxonomy developed by Fink (2003) who identified six components of “significant learning”.

\section{THE GENERATING PROCESS OF THE CONCEPT OF SUSTAINABLE \\ DEVELOPMENT}

From surveys of the history and the evolution of the concept of sustainable development (Godard 1994; Nordhaus 1998; Pezzey and Toman 2002; Vivien 2003), we show in the next subsections that the absence of consensus related to the definition of this semantically unstable concept is directly linked to its generating process. In fact, the three dimensions 
associated with sustainable development have long been addressed separately or in pairs in the literature. It is only in the 1970s that they started being addressed holistically.

\section{The winding historical path to sustainable development}

The environment and the finiteness of natural resources have been partially taken into consideration by economists for centuries. For example, the physiocrats, and more particularly F. Quesnay (1694-1774) and his “economic table”, insisted on the link between wealth and the earth. Later on, the classical economists tried to understand the dynamic process of economic growth. A. Smith and D. Ricardo reluctantly agreed on the inevitable "stationary state" due to the relative land scarcity. J.S. Mill was more prone to this idea. For him, population and capital limitations helped to meet the satisfaction of individual liberty and did not imply the slowing down of progress (Mill 1848). His position seems to be close to the idea of “frugality” first introduced by J. Bentham (1996 [1781]) and recently defended by H. E. Daly (2006). K. Marx also addressed the issue of the environment and, more surprisingly, the question of future generations as he wrote: "even a whole society, a nation, or even all simultaneously existing societies taken together, are not the owners of the globe. They are only its possessors, its usufructuaries, and, like boni patres familias, they must hand it down to succeeding generations in an improved condition” (Marx [1894], 757).

At the beginning of the twentieth century, J. A. Schumpeter (1983 [1911], 64) emphasized the need to distinguish between growth and development as he suggested: "add successively as many mail coaches as you please, you will never get a railway thereby”. Nevertheless, the debate on growth and development really emerged in the 1950s, in a context of post-war reconstruction and former colonies’ independence. For example, W.A. Lewis (1954) built a dual-sector model of economic development, in which the expansion of the industrial sector would attract rural workers, increase their income and savings, therefore generating demand 
and investments that would trickle down into the entire economy. W.W. Rostow (1959) formalised five stages of growth representing the linear sequence through which all societies were supposed to pass in order to reach modernity: traditional society, preconditions for takeoff, take-off, drive to maturity, age of mass-consumption.

In the late 1950s and the1960s, the identification of development with growth was criticized by many economists, who emphasized that development should take many other variables into account, such as poverty reduction, reduction in income inequality, improvement of living conditions, etc. (Myrdal 1957; Seers 1969).

\section{The turning point of the 1970s}

The 1970s, named the "second decade of development", by the United Nations General Assembly can be considered as a turning point in the debate on growth. First, the Club of Rome's report The Limits to Growth (Meadows et al. 1972) questioned and denounced the economic growth process and concluded that all growth scenarios (simulated by the "World3" model) would lead to the collapse of the global system. Even if its alarmist conclusions were criticized, it triggered the debate on the possibility of sustainable growth.

The same year, at the Stockholm Conference on Human Environment, M. Strong (Secretary-General of the conference) presented the concept of “ecodevelopment”. It was then promoted by the United Nations Environment Program (UNEP) and by the United Nations Conference on Trade and Development (UNCTAD) as follows: "conditions should be created for people to learn by themselves through practice how to make the best possible use of the specific resources of the ecosystem in which they live, how to design appropriate technologies, how to organize and educate themselves to this end" (UNEP-UNCTAD 1974, 11). Slowly, this concept disappeared, as it was deemed radical by the international community. The semantic shift from ecodevelopment to sustainable development is 
considered as an institutional withdrawal by O. Godard (1994): sustainable development does not involve the paradigmatic disruption that underlies ecodevelopment.

\section{The birth of the concept of sustainable development}

The first official reference to sustainable development was made by the International Union for Conservation of Nature (IUCN) in 1980. In 1983, the UN General Assembly created the World Commission on Environment and Development chaired by G. H. Brundtland to tackle the issue of the deterioration of the environment and the depletion of natural resources and their consequences on economic and social development. In 1987, the Brundtland Report defined sustainable development as: "development that meets the needs of the present without compromising the ability of future generations to meet their own needs" (WCED 1987, 43). Thus: "sustainable development is a process of change in which the exploitation of resources, the direction of investments, the orientation of technological development and institutional change are all in harmony and enhance both current and future potential to meet human needs and aspirations” (WCED 1987, 46). The economic, social, and

environmental spheres, which have become the three pillars of sustainable development, appeared in filigree. Furthermore, the report emphasized the need for equity in two complementary ways: intergenerational equity and intragenerational equity, without precisely specifying how to deal with it.

From a theoretical standpoint, three main approaches address sustainable development differently, depending on the sphere to which more emphasis is given. A first approach is “ecocentrist”. It is related to the neoclassical theory of equilibrium and growth. In brief, these authors consider environmental problems as externalities due to failures in the allocation system. They identify conditions for an economically optimal exploitation of resources and its implication for the evolution of well being (Solow 1974; Nordhaus 1994). Sustainability 
means "non declining utility" (Pezzey 1992, 14). This is close to the definition of income brought by Hicks when he identified the conditions for a long term wealth increase: income is "the amount which they [people] can consume without impoverishing themselves" (Hicks 2001 [1939], 172).

The second theoretical school brings a "biocentrist" vision focused on the supremacy of the environmental sphere. The proponents of "ecological economics" and "bioeconomics" reject the vision of an economic sphere "disembedded" from the two others. As early as in the 1960s, K. E. Boulding (1966) opposed a “close economy” to the prevailing “open economy” (which he identified as a “cowboy economy”) and developed an analogy to represent the earth as a spaceship with limited reservoirs of resources and limited carrying capacity of pollution. Nicholas Georgescu-Roegen (1971) defends the alienation of the economic process to thermodynamic rules such as the "entropy law”. Using various concepts developed in natural sciences, ecological economists argue that the social and economic spheres are conditioned by the environmental one (Costanza and Daly 1987; Daly 1990).

On top of the central place given to the market to allocate resources or to solve externality problems, another major difference between the neoclassical school and ecological economics lies in the substitutability between different kinds of capital. According to the first school, natural capital and productive reproducible capital are partially substitutable, whereas ecological economists view them as complementary rather than substitutable.

The third theoretical school, the ecodevelopment's approach introduced above, is "anthropocentrist": it insists on the supremacy of the social sphere over the environmental sphere and, finally, the economic sphere. Theoretically explored by I. Sachs (1980), ecodevelopment can be defined as a programmatic progress and, above all, as the willingness to reconcile economic development, environment preservation and social progress. To him, the following conditions are central: (i) the satisfaction of basic needs of the poor, especially 
in developing countries; (ii) the adoption of lifestyles and technologies compatible with each "ecozone" and the autonomy in decision making; (iii) ecological wisdom; (iv) citizen participation; (v) planning at the level of human communities.

In addition to the debates within the research community, the reference to sustainable development — or, more generally, to sustainability — has become common place in institutional meetings as well as within the civil society: it is presently part of collective rhetoric. When reviewing the various definitions of sustainable development, the US National Research Council (1999, 23) noted that its proponents put different emphasis on "(i) what is to be sustained, (ii) what is to be developed, (iii) the types of links that should hold between the entities to be sustained and the entities to be developed, and (iv) the extent of the future envisioned”.

The concept of sustainable development is obviously equivocal, protean and not universally understood, while it is overused. This is why we consider that the first step towards an Education for Sustainable Development consists in understanding its polysemy. The game that we have created is meant to reach this goal.

\section{ROLE PLAYING AND CRITICALLY ASSESSING SUSTAINABLE DEVELOPMENT INITIATIVES}

As has been underscored in the previous section, sustainable development is a complex concept. A synthetic view, though very restrictive and open to criticism (Sauvé 2010), is represented in figure 1. 
Figure 1: a synthetic representation of the three spheres of sustainable development




Books and lectures can certainly teach students about the multiple facets of sustainable development however, for decades, educators have been aware of "the students' passive role in the usual lecture-recitation teaching pattern” (Joseph 1970, 91) and the poor results associated with such an approach in terms of learning (Dale 1954, 43). One way to help people to understand the concept of sustainable development is to fully involve them in the learning process. Among other pedagogical tools, simulation games make people active learners and bring them to learn more than traditional lectures (Gremmen and Potters 1997; Woltjer and Watts, 2005). Furthermore, they: "help them to retain the experience as a continuing base for future learning” (Joseph 1970, 93).

For six years, we have developed a game that mostly relies on role playing and is actually a success in terms of knowledge acquisition and personal capacity building ${ }^{1}$. It was first intended for graduate students who had previously been taught about the concept of sustainable development, and had attended a few classes on topics related to sustainable development. However, variants of the game make it accessible to other audiences, from middle-school students to adults (see below). The goal of the game is to make the players discover that the concept of sustainable development encompasses economic, social and environmental dimensions that are intertwined. Meanwhile the participants are able to build critical thinking on how the concept is being overused by economic actors.

\section{Game sequencing}

The whole session lasts between two and a half and three hours, depending on the number of players. The ideal number of players is 12 but the game is relevant between 9 and 18 participants.

Before playing, students are required to work individually for a month. They have to retrieve information concerning an organization that has been randomly assigned to them and 
is undisclosed to other players. At that time, they do not know how the game will unfold (and they have no information about it before the game starts). At the end of this preliminary phase, they have to hand in a four-page assignment, which comprises three parts: (i) the organisation's official view / discourse / strategy on sustainable development issues, (ii) a critical assessment of the information collected, (iii) a short review of a concept that is related to sustainable development and the organization that has been assigned to them.

Before the game starts, the teacher prepares the classroom to materialise the three dimensions of sustainable development with chairs and stickers that are posted on the floor (figure 2). There should be a chair for each participant. 
Figure 2: classroom setting of the game




Each sticker signals two dimensions: the major sphere is indicated in capital letters, the minor sphere appears in lower cases (e.g. ECONOMIC-social, SOCIAL-environmental, etc). The major sphere relates to the organization's core activities, the minor sphere reflects the other area affected by the organization's activities. Table 1 shows examples of organizations that have been assigned to students over the years, the dimensions that the organization is expected to illustrate, and one of the associated concepts that students have explored ${ }^{2}$. 
Table 1: Examples of organizations represented in the simulation game

Organization

Total

Grameen Bank

Zipcar

Greenpeace

The Climate Group

Earthwatch Institute

NGO Survival

International

Oxfam

Education for Global

Warming Solutions

\section{Core activity}

International oil and gas company, chemicals

manufacturer

Bank offering financial services to the poor, to help them fight poverty, and stay profitable

Car sharing company

International environmental organization

International NGO aiming at a low-carbon world economy

International environmental charity for scientific

research and education

International organization supporting tribal peoples worldwide

Confederation of organizations aiming at ending poverty and injustice

NGO organizing the educational initiative

"National Teach-in on Global Warming Solutions"

\begin{tabular}{|c|c|}
\hline $\begin{array}{c}\text { MAJOR } \\
\text {-minor } \\
\text { spheres }\end{array}$ & $\begin{array}{c}\text { Suggested } \\
\text { concept }\end{array}$ \\
\hline ECO-есо & $\begin{array}{l}\text { Corporate socia } \\
\text { responsibility }\end{array}$ \\
\hline ECO-soc & Micro-credit \\
\hline ECO-env & $\begin{array}{c}\text { Energy } \\
\text { efficiency }\end{array}$ \\
\hline $\begin{array}{l}\text { ENV- } \\
\text { env }\end{array}$ & $\begin{array}{l}\text { Grassroot } \\
\text { movement }\end{array}$ \\
\hline ENV-eco & Carbon offsets \\
\hline ENV-soc & Citizen science \\
\hline SOC-soc & Land rights \\
\hline SOC-есо & Food security \\
\hline SOC-env & Clean energy \\
\hline
\end{tabular}


The participants have to prepare a five-minute speech, as if they were high ranking decision-makers, emphasizing how their organization is addressing sustainable development issues and including the concept they have previously selected. They are not allowed to dig into the paper they have handed in, so as to make their speech spontaneous and creative. Then they have to choose the chair that faces the sticker that best matches their view of the organization's approach, according to the content of the speech they intend to deliver. They are allowed to move chairs if they think it is relevant. When all the students are seated in the sphere they think is adequate, a first round of the game may start in which students have to adapt their speech to the other participants' statements, so as to make the game livelier. While a student is role playing, the student who is sitting opposite in the circle must carefully analyze whether the speech delivered is consistent with the place the speaking student has chosen, i.e. consistent with the indications on the stickers.

This feedback is used as an introduction to the second round of the game, which is much shorter and in which participants have to address the criticisms or verbal attacks that have been expressed against their organization in the first round. The last sequence of the session is devoted to wrapping up what the students have learned about the concept of sustainable development as well as its related concepts. It is worth noting that the teacher does not intervene at all in the two rounds, except to make sure the time limits are respected. The teacher may tackle questions in the concluding phase, so as to raise the students' awareness of some points that they might have overlooked otherwise.

\section{Grading}

Grading is based on the paper the students have handed in and their performance when role playing. The evaluation criteria for the paper include the relevance of the internal structure, of the critical review and of the bibliography they have gathered. The criteria 
pertaining to the role playing performance emphasize creativity, liveliness, reactivity to the other students’ performance, and critical thinking.

\section{Variants of the game}

Several variants of the game may be considered, depending on the audience and its prior awareness of the concept of sustainable development. A first variant may be to perform the game as an introduction to a course on sustainable development. The goal is threefold: raising the students' interest in class content; through exchanges with the other students, showing the students how their views may be biased; giving the teacher an overview of the students' awareness and knowledge about the concept. In this case, students do not prepare any work before the game and do not explore concepts relating to the organizations. At the beginning of the game session, they are randomly assigned an organization and given a short note about its core activities. The organizations selected by the teacher are well-known, so that the students may have some prior knowledge about them. Students may have 15 minutes to prepare their arguments and build their role.

A second variant may be to perform the game with adults not particularly aware of the concept of sustainable development (e.g. at a public event), or alternatively with middle or high schools students. In this case, the game is a kind of "hands-on" activity that allows adults or young students to express their views on sustainable development. In this variant, the wrapup session by the instructor is very important: (s)he may draw on the discussions that have unfolded to underscore potential misconceptions, expand on the concept and bring a better understanding of it.

Another variant may be to perform the game with teachers in economics, while the audience is made up of people who are only little aware of the concept of sustainable development. At the end of the game, the members of the audience cast their votes for the 
organization of which they think that the approach to sustainability best matches the concept of sustainable development. A debate may follow with the teachers, to complement the views expressed by the audience.

\section{Educating for sustainable development}

Over the years, we have noticed that, when coming up to the conclusion, the emphasis is often on the overuse of the concept by most organizations, as their approach does not properly cover the three dimensions despite their official discourse.

The primary version of the game obviously brings "significant learning" to the students (Fink 2003). We analyze below how the game addresses the six components of Fink's taxonomy of "significant learning”, to wit: (i) foundational knowledge, (ii) application, (iii) integration, (iv) human dimensions, (v) caring, (vi) learning how to learn.

In terms of foundational knowledge, the students benefit in multiple ways from the work they have carried out prior to the game, as they get a vision of the organization that has been assigned to them and of the main issues relating to the field in which it is acting. They also deepen their knowledge of the concept as they have to compare the approach adopted by the organization to what they have already heard about sustainable development in previous classes: they often realize that the dimensions associated with sustainable development spread beyond the basic economic, environmental and social tripod, into cultural and ethical spheres. Furthermore, they get further knowledge from what the other participants bring up, including from the discussion in the wrap-up session. Our tool therefore teaches a few theoretical snapshots, practical concepts, and key issues related to sustainable development, in addition to the expected basic knowledge acquisition. In all these respects, the game is a contribution to education about sustainable development. 
Application is central to the game. When role playing, students mobilise many skills: creativity (their presentation should be lively and spur reactions); communication (their messages should be clearly enunciated and understood); remaining focused (when listening to the others) and critical thinking (fruitful interactions with the others).

Integration comes from the interactions between students during the game, which are made easier by the fact that the organizations that have been carefully selected by the teacher are complementary. For instance, partnership suggestions may emerge between Oxfam and Grameen Bank, as well as between The Climate Group, Zipcar, Education for Global Warming Solutions and Earthwatch Institute. (see table 1). Integration is also mentioned by students, as the assignment prior to the game has sometimes opened doors to them: for those who have got in touch with decision-makers within the organization, they have sometimes heard about future job opportunities.

Human dimensions are enhanced during the game. When delivering their speech, students learn about themselves: they may realize that they are good orators, persuasive, creative, or conversely poor in these respects. Students also learn about the other participants: they may discover them in ways that they had not perceived so far. When using the game as an introduction (as in the first variant presented previously), it becomes an efficient ice-breaking tool.

Caring is often mentioned by the students, a few days or weeks after playing. They state that the game and the assignments have contributed to changing their views on sustainable development, and increasing their interests. Through the random distribution of the organizations, they may have been compelled to study an organization that they initially were not interested in, or did not even know. They often resist this requirement. Still, in the end, they appreciate having been able to make this move, as it has opened their eyes on new issues, moral values and often has led them to think, behave and act differently thereafter. 
Learning to learn stems from every step of the game. Students have to do research by studying numerous information sources and documents over several weeks. When preparing their speech, some tend to write all the sentences that they intend to say, while others make a note only of a few key-words. During the game, referring to their fellows' way of learning, students may then realize that the way they prepared their assignment and/or speech may not be the most appropriate way for them to do it.

In all these respects, the game is a contribution to education for sustainable development. As recently recalled by UNESCO: “education for sustainable development (ESD) helps societies to address different priorities and issues inter alia water, energy, climate change, disaster and risk reduction, loss of biodiversity, food crises, health risks, social vulnerability and insecurity. [...] ESD emphasises creative and critical approaches, long-term thinking, innovation and empowerment for dealing with uncertainty, and for solving complex problems. ESD highlights the interdependence of environment, economy, society, and cultural diversity from local to global levels, and takes account of past, present and future” (UNESCO 2009, 2).

\section{CONCLUSION}

Historically, the concept of sustainable development was built in the 1980s, and born from many debates on the nature of development, economic growth and the use of natural resources. The term has spread rapidly and is now common place in multiple arenas. However, its meaning varies widely depending on who uses it and on which of the three basic economic, environmental and social spheres primary emphasis is put. This semantic instability makes it difficult for students and the general public to grasp the stakes behind the concept of sustainable development. In this context, we have created a simulation game that aims at deepening the knowledge of the concept of sustainable development and other related notions. While role playing a decision-maker in a given organization, each player has to 
explain how their organization is involved in sustainable development and to critically examine what the other players say that they are doing to foster sustainable development. The participants are given the opportunity to develop many skills, to interact with the other players and potentially with real decision makers, learn about themselves, become more responsible citizens, and learn to learn. They highly praise the experience. All these features build a strong case for spreading the game as a tool contributing to education for sustainable development.

\section{REFERENCES}

Bentham, J. 1996 [1781]. An Introduction to the Principles of Morals and Legislation. Oxford: Clarendon Press.

Boulding, K. E. 1966. The Economics of the Coming Spaceship Earth. In Environmental Quality in a Growing Economy, ed. H. Jarret, 3-14. Baltimore: John Hopkins.

Costanza, R., and H. E. Daly. 1987. Toward an Ecological Economics. Ecological Modelling 38 (1-2): 1-7.

Dale, E. 1954. Audiovisual Methods in Teaching. Revised edition. New-York: The Dryden Press.

Daly, H. E. 2006. Sustainable Development: Definitions, Principles, Policies. In The Future of Sustainability. M. Keiner, 39-53. Dordrecht: Springer.

Daly, H. E. 1990. Toward some Operational Principles of Sustainable Development. Ecological Economics 2 (1): $1-6$.

Fink, L. D. 2003. Creating Significant Learning Experiences. San Francisco: Jossey-Bass.

Georgescu-Roegen, N. 1971. The Entropy Law and the Economic Process. Cambridge: Harvard University Press.

Godard, O. 1994. Le développement durable : paysage intellectuel. Natures-Sciences-Sociétés 2 (4): 309-322.

Gremmen, H., and J. Potters. 1997. Assessing the Efficacy of Gaming in Economic Education. Journal of Economic Education, 28 (4): 291-303.

Hicks, J. 2001 [1939]. Value and Capital: An Inquiry into Some Fundamental Principles of Economic Theory. Oxford: Oxford University Press.

International Union for Conservation of Nature. 1980. World Conservation Strategy: Living Resource Conservation for Sustainable Development. Gland: IUCN.

Joseph, M. L. 1970. Game and Simulation Experiments. Journal of Economic Education 1 (2): 91-96. 
Lewis, W. A. 1954. Economic Development with Unlimited Supplies of Labour. Manchester School 22 (2): 139191.

Marx, K. 1991 [1894]. Capital. Volume III: The Process of Capitalist Production as a Whole. London: Penguin Classics.

Meadows, D. H., D. L. Meadows, J. Randers, and W. W. Behrens III. 1972. The Limits to Growth. A Report for the Club of Rome's Project on the Predicament of Mankind. New York: Universe Books.

Mill, J. S. 1848. Principles of Political Economy with Some of their Applications to Social Philosophy (II). London: John W. Parker.

Myrdal, G. 1957. Economic Theory and Underdeveloped Regions. New York: Harper and Row.

National Research Council. 1999. Our Common Journey: Transition toward Sustainability. Washington D.C.: National Academy Press.

Nordhaus, W. D. 1994. Reflections on the Concept of Sustainable Economic Growth. In Economic Growth and the Structure of Long-Term Development, eds. L. Pasinetti and R. Solow, 309-325. London: Macmillan.

Pezzey, J. 1992. Sustainable Development Concepts. An Economic Analysis. World Bank Environment Paper 2. Washington: The World Bank.

Pezzey, J. and, M. A. Toman. 2002. The Economics of Sustainability: A Review of Journal Articles. Resources for the Future. Discussion Paper 02-03. Washington.

Rostow, W. W. 1959. The Stages of Economic Growth. The Economic History Review 12 (1): 1-16.

Sachs, I. 1980. Stratégies de l'écodéveloppement. Paris: Les Editions ouvrières.

Sauvé, L. 2010. Education et formation pour l’avènement d’une écosociété. In Le développement durable. De l'école au campus, ed. O. Blanchard, D. Lecomte, and M. C. Zélem. Paris: L'Harmattan.

Schumpeter, J. A. 1983 [1911]. Theory of Economic Development: An Inquiry into Profits, Capital, Credit, Interest and the Business Cycle. New Brunswick: Transaction Publishers.

Seers, D. 1969. The Meaning of Development. International Development Review 11 (4): 2-6.

Solow, R. 1974. Intergenerational Equity and Exhaustible Resources. The Review of Economic Studies 41: 2945.

United Nations Economic and Social Council (UN ECOSOC). 1999. Implementation of the International Work Programme on Education, Public Awareness and Training. Report of the Secretary-General. Commission on Sustainable Development, Seventh Session, April 19-30 (E/CN.17/1999/11). 
United Nations Educational Scientific and Cultural Organization (UNESCO). 2009. The Bonn Declaration. World Conference on Education for Sustainable Development. March 31-April 2.

United Nations Environment Program, and United Nations Conference on Trade and Development. 1974. The Cocoyoc Declaration. Cocoyoc: UNEP-UNCTAD.

Vivien, F.-D. 2003. Jalons pour une histoire de la notion de développement durable. Mondes en développement 31 (121): 1-21.

Woltjer, G. B. and, M. Watts. 2005. Decisions and Macroeconomics: Development and Implementation of a Simulation. Journal of Economic Education, 36 (2): 139-144.

World Commission on Environment and Development (WCED). 1987. Our Common Future. Oxford: Oxford University Press.

\footnotetext{
${ }^{1}$ A very simplified version of the game was first elaborated in 2004 during a seminar held by our colleague Catherine Figuière, to whom we are thankful. We also want to thank Alain Piallet and Willy Lavastre.

${ }^{2}$ Students may well choose other concepts than the ones suggested in the table. But they must get an agreement from the instructor about the relevance of their concept.
} 